\title{
Chapter \\ [11] \\ Avian diversity at Beas River conservation reserve under urbanization and intensive agriculture in Punjab, India
}

\author{
Sachin Kumar* and Tejdeep Kaur Kler \\ Department of Zoology, College of Basic Sciences and Humanities, \\ Punjab Agricultural University, Ludhiana 141001(Punjab), India
}

\begin{abstract}
Punjab is an agrarian state nurtured by the river Beas and Satluj with a maximum gross cropped area of $98.5 \%$ in India. River Beas had been designated as "Conservation Reserve" in 2017 and "Ramsar site" in 2019. Agriculture affects $87 \%$ of the globally threatened bird species. Birds are the most noticeable and specialized species in the river habitats; hence the abundance and distribution of birds are often readily interpreted in the context of river health and vice versa. The chapter has been designed to understand the impact of agriculture, urbanization, tree diversity and wetlands along the river on avian diversity based on literature available for the state of Punjab. The chapter aims to generate sustainable management strategies for the conservation of avian diversity at Beas river conservation reserve without hampering the development of the region. The present work reveals that agriculture intensification and urbanization are major concern for avian diversity conservation as both these factors negatively impacts the habitat specialist bird species and favors generalist and insectivore species. The study concludes that significant number of species recorded have specific niche area requirements that are completed by the river's sub-habitats including feeding, foraging, roosting and nesting therefore the whole area needs protection as a single unit.
\end{abstract}

Keywords

Agriculture, Beas, Birds, Conservation reserve, Punjab, Urbanization

$\triangle 7$ Sachin Kumar, Email: 810sachinkumar@gmail.com ( ${ }^{*}$ Corresponding author)

(C) 2021 | Agro Environ Media I Agriculture and Environmental Science Academy, Haridwar, India 


\section{Introduction}

India is a large country blessed with 47 large rivers and hundreds of small tributaries. Indian Rivers consist of Himalayan and peninsular river systems. Himalayan rivers of the country constitute three major river systems i.e., Ganga, Brahmaputra, and Indus. River Beas is an important tributary of Indus River system (Srivastava, 2007) originating in the Shiwalik hill ranges of Himachal Pradesh and feeding a large area of Punjab for its irrigation needs (Moza and Mishra, 2007). Punjab is a small state with a $1.53 \%$ area having maximum agricultural intensification with the production of $17 \%$ of wheat, $11 \%$ of rice, and $6 \%$ of cotton in the country (Kaur et al., 2018; Gulati and Juneja, 2021). Particularly, Punjab is fed by two major rivers i.e., Beas and Satluj (Grover et al., 2017). The irrigation in the state is done majorly by canal systems derived from these rivers. The underground water is another source of irrigation in the state which has decreased drastically due to unsustainable agricultural practices, and has created a cascading effect on the demand for water from canals and rivers (Srivastava et al., 2015; Kumar et al., 2018). Urbanization and the rapid growth of agriculture during the last few decades have adversely impacted the environment, water quality, and quantity of the flow of rivers (Sharma et al., 2017; Pannu, 2018; Rafie and Kumar, 2020). The gross cropped area (GCA) of the state has reached 98.5\% (Gulati et al., 2021), and there is little scope for the extension of more agricultural area in the state. The quantum of sullage, sewage and agricultural runoff has significantly increased and ran into natural drains, eventually reaching the riverine system of river Beas (Anonymous, 2019).

All these conditions created an inevitable pressure on the natural resources including, rivers and wetlands in the state. The state has only $6.12 \%$ of the total area under forest and tree cover accounting for 3,084 sq. km of the state's geographical area. Out of this, only $1181 \mathrm{sq} . \mathrm{km}$ area is under reserved and protected categorization. Several studies are available for the avian diversity of Punjab in different habitats, including agriculture (Kler and Kumar, 2015; Kaur et al., 2016; Kaur and Kler, 2018; Sethi and Kumar, 2018; Sidhu and Kler, 2018; Kaur and Kler, 2019; Dutta and Dhillon, 2020; Sidhu and Kler, 2021) urban (Kler and Kumar, 2015; Kaur et al., 2016; Kaur and Kumar, 2018; Kler et al., 2018), natural resources, village pond and wetlands (Brraich et al., 2003; Ladhar, 2002; Kler, 2009; Kaur and Kler, 2018; Kler et al., 2018; Khalid, 2019; Singh et al., 2020; Sidhu et al., 2021).

The River Beas provides key habitats for more than 500 bird species and act as a host for summer and winter migratory water birds. The river supports many species of freshwater turtles such as Indian flapshell turtle, Indian softshell turtle, Narrow-headed softshell turtle, Crowned river turtle, Spotted pond turtle, and Brown roofed turtle. Harike and Beas conservation reserve together support more than 90 fish species (RIS, 2020). River Beas was declared a conservation reserve in 2017 under section 36A of the Wildlife Protection Act 1972 by the state government of Punjab (Anonymous, 2019) and designated as the Ramsar site in 2019 (RIS, 2020). The Government of Punjab has made an action plan for conserving the river under the Directorate of Environment and Climate Change, Department of Science, Technology, and Environment (Anonymous, 2019). The action plan emphasizes regulating and cleaning the effluents into the river. River ecosystems are impacted by various stressors that precede a loss of sensitive species and an overall reduction in diversity; therefore, a successful management plan should 
include the ecological restoration of the habitat. An extensive evaluation of published studies in Punjab and areas near the river Beas were evaluated to generate the habitat management guidelines. Natural conservation of a river is considered much effective if the conservation management efforts are made focusing Hydrology, Biology, Water Quality, and the Morphology of the river (Addy et al., 2016). Birds respond very quickly to any alteration in their habitat at any scale. They are also sensitive to disturbances due to human activities as they exhibit specific habitat preferences (Ortega-Álvarez and MacGregor-Fors, 2009). Although a large amount to work is available on avian diversity in different habitats of the state, no conclusive work is available for the faunal diversity of River Beas. The present work has been produced to understand the effect of agriculture and urbanization on ecology of avian diversity in the stretch in Punjab to provide recommendations for the conservation of faunal diversity along the river Beas.

\section{History of River Beas}

River Beas is an ancient river with descriptions in Vedas. Vipasa of Mahabharata (Pandey, 2009), Hyphasis of Alexander (Crindle, 1992) were the most commonly known names of this river in ancient India. The river was named Vipas in Rig-veda, which means unfettered. The river was later named as 'Vipasa' in Sanskrit texts (Griffith, 1971). It is believed that the River Beas has been named eponym for rishi Vyasa (author of Indian Epic Mahabharata) (Pandey, 2009). River Beas has been named differently in different periods of time. The other names that were commonly used were Arjikiya (Dey, 1899), Arjikuja (Frowde, 1908), Darya-e-Siyah (Yadgaar, 1985), Beas (Al-Balazari, 1986), Biah (Babur, 1987), Dand Nurni (Fazal, 1988), Ab-i-Siyah (Sirhindi, 1990), Bipasa, Hurhari, Darya-e-Sultan Pur (Ahmad, 1990), Machala (Baqi, 1990) and Darya-e-Gobindwal (Jahangir, 1995). The present name 'Beas' was seen in the imperial gazetteer of India in 1908, describing the tributaries at that time. The chief tributaries are Chakki and Bein. The Chakki collects the drainage of the Chamba hills and joins the Beas near Mirthal, while The Bein formally called Black (Siydh) Bein rises in the Siwaliks, and joins the Beas to miles above its junction with the Sutlej (Forwde, 1908).

The river flowed in its natural phase for millions of years. In the early nineteenth century, plans were initiated to control the flow of this river for irrigation and hydroelectric power generation purposes. Two major dams were built on the river named Pong and Pandoh Dam. The former was completed in 1974 and later in 1977 (Moza and Mishra, 2007). Additionally, the river has rich biodiversity with two main Ramsar sites, i.e., Pong Dam reservoir and Harike wetland. Pong Dam reservoir, also known as Ranjit Sagar Reservoir situated behind the Pong Dam, was constructed in 1975. The reservoir was designated as 'Wetlands of international importance' under the Ramsar Convention in 2002 for its rich diversity. Further, it acts as a temporary shelter for winter migratory birds (Malik and Rai, 2019). The river merges with Satluj at Harike, where another wetland is formed named Harike wetland. This wetland was designated as Ramsar wetland designated in the year 1990 (Mabwoga and Thukral, 2014). 


\section{Course of the River}

The river originates in Shiwalik hills in the state of Himachal Pradesh and merges with the river Satluj in plains of Punjab state near Harike. River Beas is $460 \mathrm{~km}$ long and originates from two primary sources, Beas Rishi on the right of Rohtang Pass at an elevation of $4350 \mathrm{~m}$ and Beas Kund at an elevation of $4060 \mathrm{~m}$ on the South having a caveran within North-Western Himalaya. Both the streams merge at village Palchan near Manali to give the first appearance of river Beas. The approximate length of the river is $256 \mathrm{~km}$ in Himachal Pradesh (HP) and $214 \mathrm{~km}$ in Punjab. The total catchment area of the river is $38030 \mathrm{~km}^{2}$, where $12130 \mathrm{~km}^{2}$ is spread within Himachal Pradesh and $25900 \mathrm{~km}^{2}$ Punjab (Moza and Mishra, 2007; Kamboj et al., 2021).

Headwaters of the river are steep and, leading $120 \mathrm{~km}$ stretch of river with an average fall of 1 in 40 . It decreases downstream to 1 in 500 in Beas Valley. The main tributaries of Beas are Parbati, Spin, Malana Nala in the east and Solang, Manalsu, Sujion, Phojal, Sarvati in the west. The river joins Tirthan, Hansa, Bakhli, Jiuni, Suketi, Panddi, Son and Bather from Northside near district Mandi of Himachal Pradesh. Further the river flows toward district Kangra, fed by Banganga, Binwa, Chakki, Dehr, Gej, Neugal from North, and Kunah, Khairan, Maseh, Man from South. The eastern and northern tributaries of Beas are snowfed, making it a perennial river by drainage from southern slopes of Dhauladhar Mountains. The southern tributaries show fluctuation in the flow because of seasonal rains. The flow of water is maximum during monsoon and minimum in winter. In the last decades, the water quantity has been decreased (Moza and Mishra, 2007). The first major anthropogenic manipulation on the course of river is made at village Pandoh in Mandi, where an earth cum rockfill dam with $74.37 \mathrm{~m}$ height named "Pandoh reservoir" has been constructed (Kumar et al., 2007). The reservoir provides 1.58 million cusecs of water, and simultaneously, 4716 cumecs of water are diverted to river Sutlej through the Beas-Sutlej Link canal. The water is diverted via $12.38 \mathrm{~km}$ long, $8.15 \mathrm{~m}$. wide tunnel and $11.8 \mathrm{~km}$ long lined canal. Another major earth cum rock fill reservoir and dam has been constructed near village Pong in Kangra district to form Pong reservoir, also known as Ranjit Sagar Reservoir. The water spread area is 6000- 24000 ha. The water in the reservoir is utilized for multipurpose activity, mainly irrigation and power generation (Moza and Mishra, 2007).

The river enters the plains of Punjab after leaving Pong dam via Barrage at Talwara (Distt. Hoshiarpur); a large chunk of water is diverted at barrage for irrigation through Shah Nehar Canal. The canal grabs $4170-8611$ cusecs of water depending upon the season results in a wide variation in water released in the river ranging from 4.53-68840 cusecs. The river took a loop-like course and traversing through foothills of the Himachal-Nurpur area and gains some water from the Ravi-Beas Link canal made originating from Modhoptar and Chakki near Mirthal. In the way, another tributary named Sarri joins at village Vhed Pattan. The river regains its resources fully through re-induction of Shah Nehar canal near village Terrikein (Distt. Hoshiarpur); thereafter river flows unrestricted in the plains of Punjab, running through district Amritsar, Kapurthala and Firozpur for approximately $100 \mathrm{~km}$ towards Hari-Ke-Pattan (Harike). The river collects some more water in between from Chakwal Nalla at village Chakwal (Distt. Hoshiarpur) and Kali Bein near its culmination point at Harike (Moza and Mishra, 
2007). The river has higher forest cover before it enters Punjab, and after that, the forest cover decreases at a faster rate. The width of riparian zone decreases, and area get dominated by agriculture. The change in habitat along the river led to variation in the river's diversity (Anonymous, 2019; Brar et al., 2020).

\section{Water quality of Beas River}

During 2014-15 water quality analysis along with heavy metal contamination was done for river Beas at Beas Kund, Kullu, and Pong dam in Himachal Pradesh, where the maximum parameters were found in the acceptable limits during monsoon, winter, and summer seasons; however, $\mathrm{Cd}$ and $\mathrm{Pb}$ were found to be higher than acceptable limit of WHO (2011) and BIS (2012). In Punjab, agricultural lands usually receive contaminants from different sources characterized by harmful contaminants and constant bio-accumulation. River Beas has shown contamination by metals in the sediments in recent times. Kumar et al. (2018) recorded significantly high pollution levels during pre-monsoon and post-monsoon season with an ecological risk factor of $23.8 \%$, due to heavy metals present in the river. Water quality is a big concern for humankind (Brack et al., 2017), and water resources are being contaminated by various anthropogenic activities (Alam et al., 2009; 2010).

Anthropogenic activities such as agriculture, mining, and industries, produce a large quantity of heavy metals. These heavy metals are released into the aquatic environment, leading to heavy metal contamination causing the negative impact on biogeochemical cycles (Liu et al., 2003; Chabukdhara and Nema, 2012). The assembly of these sediments also causes biomagnification via the food chain (Uluturhan and Kucuksezgin, 2007; Yi et al., 2011).Increasing population and intense agricultural practices in Punjab put severe pressure on the natural resources. The whole stretch of the river has been designated as a conservation reserve in 2017. Restrictions were imposed as per Wildlife (Protection) Act, 1972 along the whole stretch (Bisht, 1999).

Lower valleys with agricultural land are prone to contamination from various sources. River Beas is no such exception when it enters the plains of Punjab. Recent studies have observed $28.5 \%$ metals contamination during the pre-monsoon season, and $42.8 \%$ of metals showed moderate to high pollution during post-monsoon and winter. Overall, the ecological risk factors (ERF) resulted in 23.8\% metals in the river, posing moderate to high ecological risk (Kumar et al., 2020; Kamboj et al., 2021). The population of Punjab has increased drastically in the last few decades and is expected to increase exponentially (PSOP, 2011).

The population of major cities around river Beas is also increasing which would negatively impact the biodiversity around the river. Exponential agricultural growth and urban development result in elevated levels of changes in land use, which cause degradation of natural habitats (Foley et al., 2005; Hanski, 2005). River ecosystems are fragile and support rich biodiversity. The present water quality status of river Beas is a matter of concern and needs more substantial efforts. 


\section{Effect of urbanization on avian diversity along the river}

Urbanization negatively affects natural habitats, woodlands, and riparian areas of streams (Keten et al., 2020). Saklani et al. (2018) have reported that avian diversity decreases as we go close to the areas having dense population. The nearest available study along rive Beas in urban landscape has shown only 17 residential bird species in urban landscape in Kapurthala (Begowal) region (Kler et al., 2015). A total of 63 species of migratory species have also been recorded in urban landscape in Punjab region (Kler and Kumar, 2015). Workers have observed that generalist species were more favored in the urban landscape, with two commensal bird species, i.e., Blue Rock Pigeon and House Crow as the most abundant species in the region of Punjab due to easy food availability (Kler et al., 2015). Urbanization along the river may favor the generalist and commensal species in the region. Major cities are usually grown around the rivers due to easy accessibility of river serveries such as drinking water, food, and transport (Groffman et al., 2003). Siddiqui et al. (2019) have reported that the urban sites are dominated by omnivore species, whereas insectivorous species dominate semi-natural, semirural, and rural natural areas. An increase in non-native bird species due to anthropogenic effects (Marzluff, 2001) is also a stumbling block that may alter the already stressed avian diversity of the region.

Electromagnetic Radiations (EMR) are an integral part of Human settlements in the present time. EMR poses significant health hazards to birds and humans. Sparrows, pigeons, parrots, and swans are some of the birds highly affected by these radiations (Surendran et al., 2020). Maximum EMR (Electromagnetic radiations) are generated from mobile towers. Various studies has been conducted in India to check the impact of mobile towers on avian diversity (Durgam et al., 2017; Kler et al., 2018; Kumar and Singh, 2018; Siddiqui et al., 2019; Surendran et al., 2020). Most of these studies have shown a negative or neutral relation of avian diversity in proximity of mobile towers. Radio frequency waves hurt the regular navigational capacities of birds (Surendran et al., 2020). Low avian abundance and breeding success near mobile towers and high voltage power transmission towers have been observed in Punjab might be due to the clandestine effect of electromagnetic radiations along with the other unforeseen factors (Kler et al., 2018). However, uncertainty exists in possible biological effects arise from electromagnetic field exposure on birds (Bhattacharya and Roy, 2013). River Beas harbors a rich avian diversity; it also hosts a large number of migratory birds at Harike wetland. Communication towers may negatively impact the richness and abundance of the species, which needs to be addressed in conservation plans.

River resources are being polluted by industrial and domestic pollutants, where exploitation of ecosystem services in river catchments areas is a well-known phenomenon under downstream effects (Maltby and Ormerod, 2011). However, river Beas also faces similar problems at a lower scale (Kamboj et al., 2021). Among all riverine organisms, birds are most noticeable, with specialized traits to exploit the habitat conditions provided by rivers (Buckton and Ormerod, 2002); hence the effects of environmental changes on the abundance and distribution of river birds are often readily interpreted (Ormerod et al., 2000) in context of river health. Conservation of Avian diversity could help to conserve the overall river biodiversity (Vaughan et al., 2007). Exotic tree and shrub species in urban habitat 
affects the natural flora and fauna (Acar et al., 2007). Due to lower nest predation and higher food availability, native bird species prefer urban areas dominated by native rather than exotic vegetation (Donnelly and Marzluff, 2004; White et al., 2005). The urban population is growing continuously and affecting biodiversity within urban environments (Seto et al., 2013). Habitat loss, fragmentation, altered species interactions, biotic homogenization, extinction of native species, and proliferation of alien species are the major impacts of urbanization on biodiversity (Grimm et al., 2008; Goddard et al., 2010; Keten et al., 2020). Avian diversity is often taken as biological indicators for the impacts of urbanization on ecosystems because they are easy to observe, identify, ecology is well known, and respond quickly to changes in habitat structure (Vandewalle et al., 2010; Fontana et al., 2011; Wenny et al., 2011). Rivers and wetlands are vital for urban ecological infrastructure. However, rivers are heavily degraded and altered along with urban cities. This phenomenon is known as urban stream syndrome. This syndrome includes alteration in chemical, physical and biological elements of the river by urban development, pollution, disturbance, and catchment inurement (Paul and Meyer, 2001; Walsh et al., 2005). Rivers flowing near urban landscape usually experience altered vegetation structure, loss of riparian forest, and reduced diversity (Urban et al., 2006). The area along urban streams is usually considered as natural ecosystems having the potential of a local hotspot. However the potential of urban streams and rivers to act as refuges for urban biodiversity has not been explored widely. Some work has been done to understand the avian diversity along urban streams (Dallimer et al., 2012; Suri et al., 2017), yet the explanation for the impact of the riparian zone of rivers on the functional configuration of urban bird communities is unknown. Although Punjab has made a roadmap for cleaning the river water (Anonymous, 2019) and protecting the river from 'urban stream syndrome,' the plan has no provision for the conservation of natural habitat to create a healthy ecosystem for avian diversity along the river Beas.

\section{Effect of agriculture on avian diversity of river system}

There are various threats to bird diversity, but agriculture alone affects $87 \%$ of the globally threatened bird species (Bli, 2008). Punjab is a small state with $1.5 \%$ area of the total area of India. Still, it alone contributed 1/3rd and 1/4th of central pool wheat and rice, respectively, as per the economic survey of 2019-20. For this purpose, the state relies on intensive agricultural practices. Prevailing condition are creating encroachment pressure on already stressed and small extents of natural habitats available in the state (Singh et al., 2020). A significant course of the river Beas flows through an intensive agricultural region of Punjab. After the adoption of new agriculture technology, including hybrid seeds, chemical fertilizer, and new agriculture practices from the mid-1960s, Punjab has made wonderful progress in the field of agriculture (Sidhu, 2005). In 1974, 73 percent area of Punjab was under agriculture, reaching 95 percent in 1983-85 (Jodhka, 2006). Furthermore, rice production had increased from 920,000 tons in 1970-71 to 13,382,000 tons in 2017-18. The intensification of agriculture has increased water scarcity and pressure on land-use changes in the state (Rafie and Kumar, 2020; Gulati et al., 2021). Although agricultural intensification has positive impacts, the natural habitats for 
specialist bird species have decreased in the region.

The state has used its natural resources at a much higher intensity after the green revolution and tilted towards a monoculture system of wheat-paddy (Grover et al., 2017; Gulati et al., 2021). A total of 189 species have been observed in the villages and agricultural landscape of Punjab, including 111 residents, 47 resident migrants, and 30 migrants with one species in the vagrant category. The diversity includes one endangered, one vulnerable, and eight near threatened species (Kler and Kumar, 2015). A total of 12 carnivorous bird species have been observed in agricultural and mixed fruit orchard of Punjab (Kaur and Kler, 2019). A mixed fruit tree orchard seems to encourage avian abundance than the mono fruit crops orchard. Tree diversity supports more avian richness and is paramount for avian conservation in the agricultural landscape of Punjab (Sidhu and Kler, 2017). Avian composition and their foraging ecology can be utilized for pest management strategies by identifying the insectivorous species for biological control in agricultural fields (Kler and Parshad, 2012). Habitat preference for some species is directly proportional to feeding, roosting, and nesting material in the area (Sohi et al., 2017).

Floodplains of a river are one of the most fragile ecosystems and have attracted humans since the dawn of civilizations. The natural land cover of these floodplains has always got the impact of anthropogenic activities. Flood plains of river Beas have also witnessed such changes. Agriculture and human settlements along the river have recorded a sharp increase in the last few decades. GCA of Punjab state is $98.5 \%$ (Gulati et al., 2021) which infers that the river Beas has agricultural lands on both sides of the river throughout its length in Punjab. The data of land use and land cover shows that anthropogenic pressure is overtaking the natural processes along the river Beas. The ratio of area under land use and land cover was 86:14 in 1989, which infers that the anthropogenic activities had already overtaken the natural ecosystems in the floodplain of Punjab. The ratio further deteriorated during the next decades to 89:11 and 93:07 for the years 2000 and 2015, respectively (Brar et al., 2020). Agricultural intensification is considered as one of the leading causes for widespread farmland biodiversity loss (Stoate et al., 2001; Tilman et al., 2001; Green et al., 2005), including reductions in the abundance and richness of many plants and invertebrate taxa (Sotherton and Self, 2000; Preston et al., 2002; Piha et al., 2007) and the declines of farmland bird populations (Chamberlain et al., 2000; Donald et al., 2001; Murphy, 2003; Newton, 2004).

The intensification of agriculture in Punjab has pushed the boundaries of the rivers in the state and has narrowed the riparian zone between the river and agricultural areas (Brar et al., 2020). The information of bird communities around crop fields and urban settlements is not entirely understood, as there is a contradiction between the results of various studies. For example, it was observed that crop fields do not show complex and diverse bird communities when compared to cattle grazing lands, this was suggested by Morris (2000), whereas MacGregor-Fors and Schondube (2011) shows that the pattern of bird communities may vary with remaining vegetation and the locality of grazing lands in the nearby landscape. At the same time, it was observed that urbanization might not consistently harm birds compared to the agricultural landscape (Bellocq et al., 2008), as some agricultural practices may be more harmful to bird communities than the impact of urban development (Faggi et al., 2008). Agricultural land use and landscape structure are the principal components of determining bird assemblage; 
however, it is not equally accurate for overall avian density, richness, diversity, or biomass. Although the state has rich avian diversity, many bird species are still habitat specialists and are not found in the agricultural landscape. Therefore, the minimum natural areas available in-state are required to be protected. Agricultural grasslands strongly and positively determined the bird assemblage (Piha et al., 2007). Studies have shown that greater avian diversity is observed in the forest than in the paddy field. The number of bird species declines if forested areas are converted to agricultural landscapes (Waltert et al., 2004; Azman et al., 2011). The commercial plantation system is also booming in Punjab to break the regular wheat-paddy cycle of the agroecosystem (Chauhan et al., 2012). Some lands are also getting converted into commercial plantations in Punjab; however, conversion of forest to commercial plantations also led to a decline in bird richness and an increase in the relative abundance of wide-ranging, adaptable species (Aratrakorn et al., 2006). Fewer species can be observed in paddy fields because these habitats are structurally simpler and offer fewer feeding niches (Fujioka and Yoshida, 2001). Relatively generalist bird species are common in commercial plantations as they have higher adaptability to unfavorable environmental conditions. Commercial plantations are generally categorized as an unfavorable environment owing to the frequent disturbance caused by humans and the low availability of food sources (Aratrakorn et al., 2006). Foraging guilds often respond to environmental conditions differently (Balestrieri et al., 2015). A decline in the avian population of long-distance migrant species of insectivore birds has been demonstrated by Vickery et al. (2014) and Gregory et al. (2007) in commercial plantation zones. Avian foraging guilds are more closely associated with plant diversity for insectivores (Sullivan et al., 2007) and frugivores bird species richness (Kissling et al., 2007). Fewer bird species have been observed in commercial plantations compared with the secondary forest and agricultural fields, especially paddy fields (Azman et al., 2011). Farming and paddy seasons are essential aspects of the abundance and distribution of birds in the area (Kelly et al., 2008; Ibáñez et al., 2010; Wood et al., 2010). Studies have suggested that paddy fields are suitable for water birds and land birds as a place to forage, breed, and shelter (Zou et al., 2006; Razafimanjato et al., 2007; Takahashi and Ohkawara, 2007; King et al., 2010; Wood et al., 2010). Flood plains of Punjab along river Beas have also witnessed the anthropogenic intervention in the landscapes of the river led to depleted natural ecosystems and land use patterns. Intensive agriculture and urbanization along the river have recorded a sharp increase in the last few decades. The impact of agriculture intensification along the rivers on avian diversity has not been studied, and literature review has shown that agricultural intensification may negatively impact the habitat specialist bird species in the state. On the other hand, generalist and insectivore species seem to increases in the regions along the river in the agricultural landscape; however, deeper studies would be required to understand the variation in species diversity in regions near rivers.

\section{Effect of trees on avian diversity}

It is a well-known fact that the natural habitat harbours healthy avian diversity. However, in the states like Punjab, it is not possible to have large forest ranges. Therefore, one of the best ways to deal with 
the problem is tree plantation. Suitable habitats can be provided to the threatened (Delarze and Ciardo, 2002) and common species by increasing the size of plantation in the region (Godreau, 1998; Britt et al., 2007); however, some adverse effects are associated with the type of plantation (Castano et al., 2019). Under the various negative implications of intensive agriculture, the state has started diverting towards tree plantation and agroforestry models. Poplar (Populus deltoides), Eucalyptus (Eucalyptus tereticornis), Dek (Melia composita and M. azedarach), Leucaena (Leucaena leucocephala), Kadam (Anthocephalus cadamba), and Teak (Tectona grandis) are grown on a commercial scale in Punjab (Chauhan, 2005). Poplar is a non-native tree species adopted at a large scale by the farmers of North India, especially Punjab, for monoculture or agroforestry (Chauhan et al., 2009; Rizvi et al. 2020). Although non-native tree and grass species have not been associated with increased predation risk for nesting birds, they impose a threat to diversity conservation. Land-cover of poplar plantation was 4\% in 2012 of the global forest and is continuously increasing (Pawson et al., 2013). Adjoining natural habitats along poplar plantations have several effects, including a decrease in bird species richness in the nearby agricultural lands and riparian forests; therefore, the practice should be avoided in areas of high conservation value (Godreau et al., 1999; Archaux and Martin, 2009). The second commercially grown tree species in Punjab is Eucalyptus, which harbor lesser avian diversity (Barlow et al., 2007; Proena et al., 2010; Calvino-Cancela, 2013; Kaur and Kumar, 2020) as compared to the native plantation. A total of 23 species has been recorded in non-native trees in Punjab. Birds are exclusively sensitive and have very close association with trees. Vegetation cover and foliage height influence avian abundance and diversity. Non-native invasive species block the growth of native flora and ultimately result in the decline of nesting sites for birds (Kaur and Kumar, 2019). Avoiding the removal of undergrowth and low branches of trees can create better foraging and nesting niches for birds (Archaux and Martin, 2009).

Banks of the river are generally covered with grass and native tree species. As River Beas has been declared as a conservation reserve, the riparian area of the river can be used to enhance the avian diversity of the region. Native vegetation along with grasslands can provide suitable habitats for native grassland breeding birds (Kennedy et al., 2009), whereas forest specialist species are strongly related to landscape characteristics. Secondary forests are essential for conservation efforts; however under the agricultural pressure closed-canopy plantation may present a viable compromise (Carrara et al., 2015). Indigenous trees like Neem (Azardirachta indica), Banyan (Ficus benghalenesis), Jamun (Syzygium cumini), Mulberry (Morus alba), Pipal (Ficus religiosa), and Sheesham (Dalbergia sissoo) harbor a significant avian diversity in Punjab (Kaur and Kumar, 2018) hence can be planted in the riparian zone of the river. At the same time, large monocultures of exotic non-native trees with short rotation times can have negative implications whereas, mixed plantations of native trees can provide similar avian diversity as to native forests of the area (Castano et al., 2019); hence, the practice of mixed plantation should be promoted in the adjoining agroforestry areas along the river.

\section{Avian diversity at small ponds and wetlands of state}

In Punjab, some documentation has been done on water-dependent birds by various authors (Kler and 
Kumar, 2015; Soni et al., 2017; Kaur et al., 2018; Soni et al., 2019; Sidhu et al., 2021). The state has many small and large wetlands where Keshopur-Miani Jheel, Chhawarian Bhangar Chhamb, Jastarwal Jheel, Mand Bharthala, and Dholbaha Reservoir are designated as wetlands of state significance. In contrast, Harike, Kanjli, and Ropar wetlands have been designated as wetlands of national importance (Ladhar, 2002). However, there is a lack of information about detailed information and trends of avian diversity along the river Beas. The majority of the work has been done on various aspects of Harike wetland in Punjab (Chopra et al., 2001; Jain et al., 2008; Sarkar and Jain, 2008; Kaur et al., 2014; Brraich and Jangu, 2016; Singh et al., 2020). Various studies have shown a decline in the water quantity of rivers, leading to degradation of the habitat and increased anthropogenic activities in the area, including agriculture (Jain et al., 2008; Malik and Rai, 2019; Singh et al., 2020).

Conservation of biodiversity is essential for the stability of ecosystems. Anthropogenic activities constitute a significant threat to biodiversity these days. It has been observed that with the growing human population, biodiversity is decreasing at a faster rate (Bilgrami, 1995; Cincotta et al., 2000; Kremen and Merenlender, 2018). Avian populations play a central role in ecosystem services and ecosystem functioning and provide economic benefits like seed dispersal and pollination. They also play a role in the restoration of distressed ecosystems (Sekercioglu et al., 2004). The avian diversity along the rivers is generally got impacted by agricultural intensification and urbanization. Flood plains of river Beas are fertile and best suitable for agriculture that makes the river habitat prone to habitat degradation.

Land use and land cover changes are responsible for the loss of ecosystem services of wetlands worldwide. Anthropogenic activities have severely affected the habitat of the Pong dam wetland posing risks of habitat degradation destruction. In the last decade, the barren area has decreased to half while the agricultural area has increased by $159 \%$. Rapid conversion of scrubland land for agriculture purposes has created severe pressure in wetland existence. Under the various anthropogenic and natural pressures, the survival age of the wetland has been estimated to be about 100 years (Malik and Rai, 2019). The case of Harike wetland on river Beas is almost the same. All these conditions can severely change the avian composition of the region, and many essential bird species could get swept out of the region.

The bird species richness is significantly associated with the percent cover of native habitat; however, fragmentation tolerant bird species remains consistent in the region. Riparian banks of rivers exhibit both high avian species richness and abundance. They may act as migration dispersal corridors on a regional scale (Bolger et al., 2001) which might get negatively affected by dams and other flood control measures leading to alter the natural river flow system. Artificial structures like dams regulate the flow of the river and can impact the abundance and richness of birds via changes in habitat parameters, which provided food and shelter to birds near dam areas (Wu et al., 2017). Studies have suggested that reservoirs play a vital role as staging and wintering areas for migratory birds, especially waterfowls (Wang et al., 2013; Ali et al., 2011); however, the extent of the repercussions of dam operations is still not known. Most of the studies are done for studying the avian diversity, richness, and abundance of reservoirs made for the rivers. However, the effect on downstream river flow and its effect on avian 
diversity still needs to be understood. The formation of ponds along rivers is a natural phenomenon. These ponds can be seasonal and sometimes perennial fed by river water (Williams and Fryirs, 2020; Ren et al., 2018). Ponds play a significant role in maintaining rich avian diversity by unique habitat and ecosystem services (Smith et al., 2002; Cereghino et al., 2014; Sidhu et al., 2021). Ponds act as a tiny but complete habitat for various plants, insects, amphibians, fish, reptiles, birds, and mammals (Froneman et al., 2001; Fairchild et al., 2005; Sidhu et al., 2021), where birds play major tertiary roles in the ecological pyramid (Lu et al., 2007; Ma et al., 2010). Various studies in Punjab on ponds have shown significant avian species richness with water-dependent and terrestrial birds (Kaur et al., 2018; Kaur and Kler, 2018; Sidhu et al., 2021). The village ponds of Punjab are typically recognized by the presence of agricultural fields, weeds, heaps of cattle dung on the side of the pond, which acts as an abundant source of food supply for highly diverse waders and mud probing bird species. At the same time presence of greater tree diversity and wild vegetation near ponds supports more bird species richness (Mahesh et al., 2018; Mishra et al., 2019; Soni et al., 2019; Sidhu et al., 2021), where rich floral diversity plays a significant role in maintaining migratory and wintering waterbirds (MacroMendez et al., 2015; Mahesh et al., 2018).

Most of the wetlands in the state are lost due to a decrease in the water available in wetlands, including Bhupinder Sagar, Chhangali Chhamb, and Rahon de Chhamb. Reduced water flow, siltation, and encroachment are significant reasons for the degradation and loss of the biological diversity of the wetlands (Ladhar, 2002). Harike wetland that harbors the maximum avian abundance and richness faces the same challenge, and the landscape of the wetland is changing (Singh et al., 2020). Ponds and wetlands along the rivers can play a vital role in the conservation of avian diversity. Therefore these areas should also be taken into consideration for conservation reserves. Plantation of native weeds, shrubs, and trees can help in increasing the avian diversity of ponds and wetlands.

\section{Importance of riparian zone of river system}

The adjoining area of the river bank and flood plains is typically known as riparian zone of the river. This corridor supports aquatic life and riparian wildlife in a number of ways (Collins et al., 2010). In a typical system, riparian zones are generally known as Ecotones between terrestrial and aquatic habitats of a river (Sabo et al., 2005). Terrestrial and freshwater habitats are linked via riparian zones through physical and energy fluxes (Burdon and Harding, 2008; Johnson and Hering, 2009). These habitats are sensitive to land-use changes due to the high edge-to-area ratio (Martin et al., 2006). Anthropogenic activities continuously create a threat to riparian habitats by casing pollution and progressive encroachment of catchment areas along rivers for human use (Allan, 2004). Birds get ample food from emerging insects and various other sources provided by the river and its riparian area (Nakano and Murakami, 2001; Baxter et al., 2005). Various processes directly influence birds in riparian areas; therefore, they are considered valuable indicators of the river ecosystem. Bird surveys are generally more cost-effective than classical biological indicators (Mattsson and Cooper, 2006; Vaughan et al., 2007). Francl and Schnell (2002) have observed that birds are more responsive to human disturbances 
than mammals, fish, and macrobenthos in riparian habitats. Bird species that occupy high trophic levels appeared negatively affected. Their abundance and distribution of avian species at higher trophic levels are negatively affected by urbanization and agricultural development ( $\mathrm{O}^{\prime}$ Connor et al., 2000; Bryce et al., 2002; Lussier et al., 2006; Mattsson and Cooper, 2006).

Riparian zones along the irrigation canals have been studies in Punjab along the Sidhawan canal. A significant avian diversity with $37.25 \%$ of the bird species falling under scare to the rare category was observed in the zone (Kler, 2009). The riparian zone of the river Beas is much broader and less disturbed than the canal. Therefore, there is a high probability of finding rich avian diversity. Rivers provide complex habitats with distinct resources allowing several species to coexist. The obligate riverine birds are diverse in the world with high topographic variation (Buckton and Ormerod, 2002; Buckton and Ormerod, 2008). River birds potentially suitable indicators of river quality ad they get affected at multiple scales by both aquatic and terrestrial changes along the rivers (Larsen et al., 2010). Global environmental changes have affected the Himalayan river systems, including glacial retreat, urban encroachment modification of catchments, and riparian zones (Manel et al., 2000). The ecological outcomes of these modifications, including the impact on avian diversity along the rivers, are poorly understood. Several anthropogenic degradation activities have made the river less habitable for avian communities, including agricultural intensification, disturbed hydrology, invasive plants, degraded habitat, alterations of channels, reduced biodiversity; and dams (Sinha et al., 2019). Almost all parameters can be seen along the river Beas. Generally, avian abundance is higher on rivers sides (Mason et al., 2006; O'Neal Campbell, 2008). Avian abundances along the rivers are positively correlated with vegetation and stream size (Ivicheva et al., 2019). Both water birds and terrestrial birds benefit from riparian nutritional pathways along the rivers (Jackson et al., 2020). Therefore, habitat monitoring along rivers is crucial for the conservation of avian abundance and diversity.

The riparian area provides a complex and diverse terrestrial habitat with unique vegetation compared to adjoining areas. Therefore these areas generally have distinct avian composition and richness. Various studies have been done to understand the impact of local habitat structures in riparian zones on species diversity (Martin et al., 2006; Palmer and Bennett, 2006; Palmer et al., 2008; Pennington et al., 2008; Berges et al., 2010; Bennett et al., 2014; Gomez et al., 2016; Liang et al., 2018). Studies have shown that avian richness is positively related to the width of riparian habitats in where trees usually play an important role (Shirley and Smith, 2005; Hillman et al., 2016; Nimmo et al., 2016). Complex landscapes in riparian strips attract a higher number of bird species (Woinarski et al., 2000; Bennett et al., 2014; Berduc et al., 2015; Terraube et al., 2016), while livestock grazing in the region can negatively impact bird species richness (Jansen and Robertson, 2001; Martin and Possingham, 2005; Nelson et al., 2011). The other decisive factor affecting species richness in riparian zones includes climate factors, such as precipitation and temperature ( $\mathrm{Li}$ et al., 2013). Riparian landscapes are beneficial to biodiversity and ecosystem functions in tropical areas (Luke et al., 2019). The tree diversity along rivers sides is generally rich with a higher number of old trees. Trees are a vital element of nature and play an essential role in maintaining the balance of nature. They have a long life span and die slowly with time. During their life span, they support many organisms to co-exist and assist in completing the life process. The trees 
may be alive or dead, but they are defined as habitat trees if they act as a habitat for some or other species. These trees provide ecological niches (microhabitats) such as cavities, large dead branches, epiphytes, sap runs, bark pockets, cracks, or trunk rot. These habitat trees have different names based on their characteristics, i.e., ancient or monumental trees have remarkable age or size, whereas cavity trees host cavity-nesting species such as woodpeckers. Habitat trees primarily host avian biodiversity and harbor many endangered species of birds. Around 10-25\% of bird species are benefited from deadwood and habitat trees. Many threatened organisms in the forest ecosystems depend upon these habitat trees. The role of old trees has caught the attention of humans as they play an important role in managing the habitat of a forest. They also have consequently acquired a symbolic role in the life of humans, either directly or indirectly (Butler et al., 2013). Every taxon has its role, and single biota reflects its importance. Birds have been generally regarded as a critical factor in monitoring the biodiversity of an area. Birds are unlikely to be an indicator taxon for other biotas. They can be used to monitor greater or less effort than other biotic components (Mac Nally et al., 2004). Birds also help monitor climate changes, habitat fragmentation, with a mounting focus on habitat quality (Major et al., 2001).

The diversity and abundance of birds are strongly linked with tree diameter, height, bark thickness, dried wood canopy, and tree age. Old trees provide cracks, wide cavities, fruits, loose bark, and other microhabitats that attract birds for feeding, foraging, roosting, and nesting. Thus, old trees provide dwelling grounds for bird diversity. Habitat trees are known for their role in forest biodiversity and the ecological services provided by them. As a result, foresters consider them optimistically. These trees offer habitat for various species, and when they fall, they become a source of woody debris and finally, through decay, contribute to maintaining ecosystem functions via nutrient cycling (Larrieu and Cabanettes, 2012).

During the last few decades, the number of habitat trees has increased in some parts of developed countries. However, the conservation of older, dead, and dried trees is part of government policies applicable to the government-owned forest in India, not favoring the conservation of these trees. The future of habitat trees on private lands in urban areas and villages will influence the conservation policies. So, conservation policies will be needed to protect these habitat trees. The old trees act as a substrate for a significant part of forest biodiversity, so particular attention should be given to old trees. On realizing the importance of old trees, several countries have promoted their preservation and are being inventoried. Therefore, coordinated measures should be taken to protect habitat trees and their microhabitats, and it should be of prime concern in the present day scenario (Saresh et al., 2018).

River buffer strips provide a wide range of ecosystem services, including enhancing the aesthetic value, protecting biodiversity, mitigating pollution, and provide freshwater systems. The multifunctional nature of river systems makes it difficult to develop management prescriptions, results in complex plans with a review of parameters like conflicts, interactions, and synergies between the services offered (Cole et al., 2020). Such a diverse ecosystem provides a range of habitats for different species and leads to higher species richness in the area. Avian diversity also gets influenced, and habitat 
heterogeneity provides higher avian abundances and diversity in such areas (Lorenzón et al., 2016). The presence of non-native plants species may alter riparian community's structure by competing with native species and hindering the restoration of degraded areas (Brooks et al., 2004). Punjab is not an exception. Many invasive species have entered into Punjab via anthropogenic activities (Dhami, 2018). The interacting hydrological and ecological processes of functional riparian support biodiversity and provide critical ecosystem services, including flood, water, and quality habitat (Cole et al., 2020). The habitat structure of river Beas has got deformed up to some extent, and the hydrology of the river has been changed for irrigation and electricity production (Moza and Mishra, 2007). The water quality index of River Beas has also decreased towards Harike (Kumar et al., 2017). River Beas was declared a conservation reserve in 2017 under section 36A of the Wildlife Protection Act 1972 and designated as a Ramsar site in 2019 (Anonymous, 2019; RIS, 2020). A wide range of efforts is required to understand, monitor, and restore the habitats along the river. The nesting of birds in the riparian zone of the river is an essential part of sustaining the avian diversity in the area. Restoration of hydrologic function unrelated to riparian deciduous vegetation for nesting and foraging can improve habitat quality for birds (Campos et al., 2020). Therefore the present study has been done to monitor and collect the crucial information required for the development of conservation strategies for the newly built conservation reserve.

\section{Conclusion and recommendations}

Effective natural conservation of a river should focus on management efforts emphasize hydrology, biology, water quality, and morphology of the river (Addy et al., 2016). In the case of the river Beas Conservation Reserve, it should be taken into consideration that the river flows through a state practicing intensive agriculture. The floodplain, and more specifically the riparian zone of the river, is the last shelter for the wildlife diversity, specifically to the habitat specialist bird species in the state. Along with this, Beas Conservation Reserve connects the two wetlands of international importance (Harike and Pong) harboring rich avian diversity and hosts thousands of migratory birds every year. It acts as a corridor for the faunal diversity to move between the two, especially avian and fish species. There is a need for a more scientific approach to conserving the overall habitat of the river. On the basis of the above study, the following management strategies are recommended:

- Agricultural land use and landscape structure near the floodplain zone of the river is principal component for overall avian density, richness, and diversity. The state has rich avian diversity with a significant number of habitat specialist species that are not found in an agricultural landscape. The minimum natural areas like riparian zones of the river and small seasonal and perennial ponds in flood plains of the river should be protected.

- Agriculture intensification along the rivers negatively impacts the habitat specialist bird species; however, it seems to favors generalist and insectivore species. Paddy fields may increase the diversity in the region, whereas crops like maize should be avoided near the river zone as it may 
attract more generalist species that may damage the crop and create competition for the species living in the riparian zone. However, more deep studies would be required to understand the variation in species diversity and its impact on agriculture near rivers.

- Native trees like Neem (Azadirachta indica), Banyan (Ficus benghalenesis), Jamun (Syzygium cumini), Mulberry (Morus alba), Pipal (Ficus religiosa), and Sheesham (Dalbergia sissoo) harbor a rich avian diversity in Punjab; hence these species should be promoted for plantation in the riparian zone of the river.

- Generally, the banks of the river are covered with native grasses and native tree species. Native vegetation, including trees and grasses, provides suitable habitat for native breeding birds. Therefore plantation of native grass species during plantation drives should be taken into consideration along the bank of the river.

- The most prevalent tree species in agroforestry of Punjab are Poplar (Populus deltoides), Eucalyptus (Eucalyptus tereticornis), Dek (Melia composita and M. azedarach), Leucaena (Leucaena leucocephala), Kadam (Anthocephalus cadamba), and Teak (Tectona grandis). Poplar has been adopted at large scape by farmers for agroforestry, but the poplar plantation near riparian zones should be avoided as it negatively affects the avian diversity of the region. Agro-forestry using Dek, Leucaena, Kadam, and Teak should be more favorable for conservation and increase the avian diversity along the river in agricultural fields.

- Large-scale monocultures of exotic non-native trees with a short rotation period can have negative implications, whereas mixed plantations of native trees, including orchards, should be promoted in the regions adjoining agroforestry areas along the river.

- Urbanization along the rivers is inevitable, which comes with the problem of industrial pollutants, sewage waste, and EMR in the form of mobile towers. The government is already working on industrial pollutants and sewage waste; however, there are no guidelines for mobile towers in the region. Studies in the region have shown low avian abundance and breeding success near mobile towers and high voltage power transmission towers. It will be appropriate to avoid the installation of mobile towers near the conservation reserve.

- Sensitization of the local people living along the river is important at the first step. This will help deal with the first problem of encroachment of the land, which is the last host for specialist species.

- The region between Talwara barrage and Mirthal has rich faunal and floral diversity; however, there is a scarcity of water between these courses of the river. Without sufficient water supply, it will be difficult to keep the river's habitat healthy and functional; therefore, there is a need to increase the amount of water released into the river.

- The river merges with Satluj at Harike, forming a large wetland known as Harike wetland. This region of the river has one of the richest avian diversity in north India. Land-use changes and decreases in water levels are responsible for the loss of ecosystem services of wetlands around the world. Harike is a wetland of international importance; however, land-use changes have been 
reported in recent times in the wetland area. It may alter the avian diversity of the wetland, so it needs to be addressed as early as possible.

- Generally, avian abundance is higher on rivers sides and is positively correlated with vegetation and stream size. Both water birds and terrestrial birds get benefited from riparian nutritional pathways along the rivers. Around $10-25 \%$ of bird species are benefited from deadwood and habitat trees. The natural habitat of the riparian zone of the river consists of native trees of all age groups, shrubs, and grasses. Older trees, alive or dead, need to be protected in the riparian zone as they ecological niches (microhabitats) in the form of cavities, epiphytes, sap runs, bark pockets, cracks, trunk rot, etc. for a number of avian species.

- The presence of non-native and invasive plants species may alter species community structure by competing with native species and hindering the restoration of degraded areas. Many invasive species have entered into Punjab via anthropogenic activities, including agriculture. Constant monitoring is required to protect the region for maintaining a healthy ecosystem along the river.

\section{References}

Acar, C., Acar, H. and Eroğlu, E. (2007). Evaluation of ornamental plant resources to urban biodiversity and cultural changing: a case study of residential landscapes in Trabzon city Turkey. Building and Environment, 42(1): 218-229.

Addy, S., Cooksley, S., Dodd, N., Waylen, K., Stockan, J., Byg, A. and Holstead, K. (2016). River Restoration and Biodiversity, IUCN, pp. 1-52.

Ahmad, N.D. and Muhammad, A.Q. (1990). The Tabaqat-i-Akbari, Urdu Science Board, Lahore, pp. 279.

Alam, M.Z., Ahmad, S., and Malik, A. (2009). Genotoxic and mutagenic potential of agricultural soil irrigated with tannery effluents at Jajmau (Kanpur), India. Archives of Environmental Contamination and Toxicology, 57(3): 463-476.

Alam, M.Z., Ahmad, S., Malik, A., and Ahmad, M. (2010). Mutagenicity and genotoxicity of tannery effluents used for irrigation at Kanpur, India. Ecotoxicology and Environmental Safety, 73(7): 1620-1628.

Al-Balazari, A.Y. and Abul, K.M. (1986). Fatuh-ul-Baldan, Karachi: Nafees Academy. pp. 623.

Ali, Z., Shelly, S.Y., Bibi, F., Joshua, G., Khan, A.M., Khan, B.N. and Akhtar, M. (2011). Pe-culiarities of Mangla Reservoir: biodiversity with sustainable use options. Journal of Animal and Plant Sciences, 21: 372e380.

Allan, J.D. (2004). Landscapes and riverscapes: the influence of land use on stream ecosystems. Annual Review of Ecology Evolution and Systematics, 35: 257-284.

Anonymous (2019). Action Plan for Clean River Beas, Directorate of Environment and Climate Change, Department of Science, Technology and Environment, Government of Punjab, pp. 5-83.

Aratrakorn, S., Thunhikorn, S., Donald, P.F. (2006). Changes in bird communities following conversion of lowland forest to oil palm and rubber plantations in southern Thailand. Bird Conservation International, 16(1): 71-82.

Archaux, F. and Martin, H. (2009). Hybrid poplar plantations in a floodplain have balanced impacts on farmland and woodland birds. Forest Ecology and Management, 257(6): 1474-1479.

Azman, N.M., Latip, N.S. A., Sah, S.A.M., Akil, M.A.M.M., Shafie, N.J. and Khairuddin, N.L. (2011). Avian diversity and feeding guilds in a secondary forest, an oil palm plantation and a paddy field in Riparian areas of the Kerian River Basin, Perak, Malaysia. Tropical Life Sciences Research, 22(2): 45.

Babur, Annette, S. Beveridge (tr.) (1987). Babur, Lahore: Sang-e-Meel Publications. pp. 458.

Balestrieri, R., Basile, M., Posillico, M., Altea, T., De Cinti, B., and Matteucci, G. (2015). A guild-based approach to assessing the influence of beech forest structure on bird communities. Forest Ecology and Management, 356: 216-223. https:// doi.org/10.1016/j.foreco.2015.07.011 
Baqi, A. and Hameed Yazdani (tr.) (1990). Muqamat-i-Daudi, Naqoosh Press, Lahore, pp. 122.

Barlow, J., Gardner, T.A., Araujo, I.S., Avila-Pires, T.C., Bonaldo, A.B., Costa, J.E., Esposito, M.C., Ferreira, L.V., Hawes, J., Hernandez, M.I.M., Hoogmoed, M.S., Leite, R.N., Lo-Man-Hung, N.F., Malcolm, J.R., Martins, M.B., Mestre, L.A.M., Miranda-Santos, R., Nunes-Gutjahr, A.L., Overal, W.L., Parry, L., Peters, S.L., Ribeiro-Junior, M.A., da Silva, M. N.F., da Silva Motta, C. and Peres, C.A. (2007). Quantifying the biodiversity value of tropical primary, secondary, and plantation forests. Proceedings of National Academy of Sciences, USA, $104: 18555-18560$.

Baxter, C.V., Fausch, K.D. and Saunders, W.C. (2005). Tangled webs: reciprocal flows of invertebrate prey link streams and riparian zones. Freshwater Biology, 50: 201-220.

Bellocq, M.I., Filloy, J. and Garaffa, P.I. (2008). Influence of agricultural intensity and urbanization on the abundance of the raptor chimango caracara (Milvago chimango) in the Pampean region of Argentina. Annales Zoologici Fennici, 45: 128-34.

Bennett, A.F., Nimmo, D.G., and Radford, J.Q. (2014). Riparian vegetation has disproportionate benefits for landscape- scale conservation of woodland birds in highly modified environments. Journal of Applied Ecology, 51: 514-523. https:// doi.org/10.1111/1365-2664.12200.

Berduc, A., Lorenzon, R.E. and Beltzer, A.H. (2015). Bird diversity patterns along a latitudinal gradient of riparian forests from Middle Parana River. Argentina Revista Mexicana De Biodiversidad, 86: 419-430. https://doi.org/10.1016/ j.rmb.2015.04.003

Berges, S.A., Moore, L.A.S., Isenhart, T.M., and Schultz, R.C. (2010). Bird species diversity in riparian buffers, row crop fields, and grazed pastures within agriculturally dominated watersheds. Agroforestry Systems, 79: 97-110. https:// doi.org/10.1007/s10457-009-9270-6

Bhattacharya, R., and Roy, R. (2013). Impacts of Communication Towers on Avians: A Review 1. International Journal of Innovative Research in Science, Engineering and Technology, 4(1):137-139.

Bilgrami, K.S. (1995). Concepts and Conservation of Biodiversity. CBS Publishers and Distributors, Delhi. pp. 429-51.

Bisht, S.S. (1999). A critical review of the schedules of the Wildlife (Protection) Act, 1972 and their amendments. Indian Forester, 125(10): 943-962.

Bli. (2008). State of the world's birds: Indicators for Our Changing World. Bird Life International, Cambridge, UK. pp. 12-13.

Bolger, D.T., Scott, T.A. and Rotenberry, J.T. (2001). Use of corridor-like landscape structures by bird and small mammal species. Biological conservation, 102(2): 213-224.

Brack, W., Dulio, V. and Ågerstrand, M. (2017). Towards the review of the European Union Water Framework Directive: recommendations for more efficient assessment and management of chemical contamination in European surface water resources. Science of Total Environment, 576: 720-737.

Brar, G.S., Chandel, V.B. and Brar, K.K. (2020). Assessing Land Use and Land Cover Change in River Beas Floodplain, Punjab. Current World Environment, 15(1): 52.

Brraich, O.S. and Jangu, S. (2016). Comparative account of accumulation of heavy metals and structural alterations in scales of five fish species from Harike Wetland, India. Iranian Journal of Ichthyology, 3(4): 275-282.

Brraich, O.S., Ladhar, S.S. and Johal, M.S. (2003). New record from Harike wetland, Punjab, Ramsar site. Punjab Fisheries Bulletin, 23: 35-36.

Bryce, S.A., Hughes, R.M. and Kaufmann, P.R. (2002). Development of a bird integrity index: using bird assemblages as indicators of riparian condition. Environmental Management, 30: 294-310.

Buckton, S.T. and Ormerod, S.J. (2002). Global patterns of diversity among the specialist birds of riverine land-scapes. Freshwater Biology, 47(4): 695-709.

Buckton, S.T. and Ormerod, S.J. (2008). Niche segregation of Himalayan river birds. Journal of Field Ornithology, 79(2):176-185.

Burdon, F.J. and Harding, J.S. (2008). The linkage between riparian predators and aquatic insects across a stream-resource spectrum. Freshwater Biology, 53: 330-346.

Calviño-Cancela, M. (2013). Effectiveness of eucalypt plantations as a surrogate habitat for birds. Forest Ecology and Management, 310: 692-699.

Campos, B.R., Burnett, R.D., Loffland, H.L. and Siegel, R.B. (2020). Bird response to hydrologic restoration of montane riparian meadows. Restoration Ecology, 28(5): 1262-1272. 
Carrara, E., Arroyo-Rodríguez, V., Vega-Rivera, J.H., Schondube, J.E., de Freitas, S.M. and Fahrig, L. (2015). Impact of landscape composition and configuration on forest specialist and generalist bird species in the fragmented Lacandona rainforest, Mexico. Biological Conservation, 184: 117-126.

Castano-Villa, G.J., Estevez, J.V., Guevara, G., Bohada-Murillo, M. and Fonturbel, F.E. (2019). Differential effects of forestry plantations on bird diversity: a global assessment. Forest Ecology and Management, 440: 202-207.

Cereghino, R., Boix, D., Cauchie, H-M., Martens, K. and Oertli, B. (2014). The ecological role of ponds in a changing world. Hydrobiologia, 723: 1-6. https://doi.org/10.1007/s10750-013-1719-y

Chabukdhara, M. and Nema, A.K. (2012). Assessment of heavy metal contamination in Hindon River sediments: a chemometric and geochemical approach. Chemosphere 87(8): 945-53.

Chamberlain, D.E., Fuller, R.J., Bunce, R.G.H., Duckworth, J.C. and Shrubb, M. (2000). Changes in the abundance of farmland birds in relation to the timing of agricultural intensification in England and Wales. Journal of Applied Ecology 37: 771-788.

Chauhan, S.K. (2005). Toward agroecological health: diversifying traditional crop rotation through agroforestry in Punjab, India. APANews, (27): 3-6.

Chauhan, S.K., Nanda, R.K., and Brar, M.S. (2009). Adoption of poplar-based agroforestry as an approach for diversified agriculture in Punjab. Indian Forester, 135(5): 671.

Chauhan, S.K., Sharma, R. and Dhillon, W.S. (2012). Status of intercropping in poplar based agroforestry in India. Forestry Bulletin, 12: 49-67.

Chopra, R., Verma, V.K. and Sharma, P.K. (2001). Mapping, monitoring and conservation of Harike wetland ecosystem, Punjab, India, through remote sensing. International Journal of Remote Sensing, 22(1): 89-98.

Cincotta, R.P., Wisnewski, J. and Engelman, R. (2000). Human population in the biodiversity hotspots. Nature, 404(6781): 990-992.

Cole, L.J., Stockan, J., and Helliwell, R. (2020). Managing riparian buffer strips to optimise ecosystem services: A review. Agriculture, Ecosystems \& Environment, 296: 106891.

Collins, A.L., Walling, D.E., McMellin, G.K., Zhang, Y., Gray, J., McGonigle, D. and Cherrington, R. (2010). A preliminary investigation of the efficacy of riparian fencing schemes for reducing contributions from eroding channel banks to the siltation of salmonid spawning gravels across the south west UK. Journal of Environmental Management, 91(6): 1341-1349.

Crindle, J.W.M. (1992). The Invasion of India by Alexander the Great as Described by Arrian, Q Curtius, Diodoros,Plutarch and Justin, Indus Publications, Karachi, 121-281.

Dallimer, M., Rouquette, J.R., Skinner, A.M., Armsworth, P.R., Maltby, L.M., Warren, P.H. and Gaston, K.J. (2012). Contrasting patterns in species richness of birds, butterflies and plants along riparian corridors in an urban landscape. Diversity and Distributions, 18(8): 742-753.

Dey, N.L. (1899). The Geographical Dictionary of Ancient and Medieval India, Low Price Publication Delhi 1971 5-7.

Dhami, D.K. (2018). Alien invasives of family asteraceae In Punjab (India). International Journal of Innovative Research and Advanced Studies, 5(1): 312-315.

Donald, P.F., Green, R.E. and Heath, M.F. (2001). Agricultural intensification and the collapse of Europe's farmland bird populations. Proceedings of the Royal Society of London B, 268: 25-29.

Durgam, D.K., Sao, S., and Singh, R.K. (2017). Effect of mobile tower radiation on birds in bijapur district, Chhattisgarh. World Journal of Pharmacy and Pharmaceutical Sciences, 6: 1221-1229.

Dutta, S., and Dhillon, S.S. (2020). Structural transformation of Punjab Agriculture and its environmental implications. Indian Journal of Economics and Development, 16(4): 533-546.

Faggi, A.M., Krellenberg, K., Castro, R., Arriaga, M. and Endlicher, W. (2008). Biodiversity in the Argentinean Rolling Pampa Ecoregion: changes caused by agriculture and urbanisation. In: Marzluff, J.M., Shulenberger, E., Endlicher, W., Alberti, M., Bradley, G., Ryan, C., Simon, U. and Zum, B.C. (ed) Urban ecology: an international perspective on the interaction between humans and nature, Springer, New York, pp. 377-89.

Fairchild, G.W., Anderson, J.N. and Velinsky, D.J. (2005). The trophic state 'chain of relationships' in ponds: does size matter? Hydrobiologia, 539: 35-46.

Fazl, A., Muhammad, F.A. (1988). Ain-i-Akbari, Sang-e-Meel Publications, Lahore, 1019-1037. 
Foley, J.A., DeFries, R., Asner, G., Barford, C., Bonan, G., Carpenter, S., Chapin, F., Coe, M., Daily, G., Gibbs, H., Helkowski, J., Holloway, T., Howard, E., Kucharik, C., Monfreda, C., Patz, J., Prentice, C., Ramankutty, N. and Snyder, P. (2005). Global consequences of land use. Science, 309: 570-574.

Fontana, S., Sattler, T., Bontadina, F., and Moretti, M. (2011). How to manage the urban green to improve bird diversity and community structure. Landscape and Urban Planning, 101: 278-285.

Francl, K.E. and Schnell, G.D. (2002). Relationships of human disturbance, bird communities, and plant communities along the land-water interface of a large reservoir. Environmental Monitoring and Assessment, 73: 67-93.

Froneman, A., Mangnall, M.J., Little, R.M. and Crowe, T.M. (2001). Waterbird assemblages and associated habitat characteristics of farm ponds in the Western Cape, South Africa. Biodiversity and Conservation, 10: 251-270. https:// doi.org/10.1023/A:1008904421948.

Frowde, H. (1908). Beas: The Imperial Gazetteer of India, 7: 138.

Fujioka, M. and Yoshida, H. (2001). The potential and problems of agricultural ecosystems for birds in Japan. Global Environmental Research, 5(2):151-161.

Goddard, M.A., Dougill, A.J. and Benton, T.G. (2010). Scaling up from gardens: Biodiversity conservation in urban environments. Trends in Ecology and Evolution, 1175: 1-9.

Godreau, V., Bornette, G., Frochot, B., Amoros, C., Castella, E., Oertli, B., Chambaud, F., Oberti, D. and Craney, E. (1999). Biodiversity in the floodplain of Saône: a global approach. Biodiversity and Conservation 8: 839-864.

Gomez, D., Rivera, L., Politi, N. and Ruggera, R. (2016). Bird assemblages of Riparian forests of Premontane forests in northwestern Argentina. Ornitologia Neotropical, 27: 47-57.

Green, R.E., Cornell, S.J., Scharlemann, J.P.W. and Balmford, A. (2005). Farming and the fate of wild nature. Science, 307: 550555.

Gregory, R.D., Vorisek, P., Van strien, A., Gmelig meyling, A.W., Jiguet, F., Fornasari, L. and Burfield, I.J. (2007). Population trends of widespread woodland birds in Europe. Ibis, 149:78-97. https:// doi.org/10.1111/j.1474-919X.2007.00698.x

Griffith, R.T.H. (1971). The Hymns of Rig Veda, Chowkhamba Sanskrit Series Office, Varanasi, 1: 353-432.

Grimm, N.B., Faeth, S.H., Golubiewski, N.E., Redman, C.L., Wu, J., Bai, X., and Briggs, J.M. (2008). Global change and the ecology of cities. Science, 319(5864): 756-760.

Groffman, P.M., Bain, D.J., Band, L.E., Belt, K.T., Brush, G.S., Grove, J.M. and Zipperer, W.C. (2003). Down by the riverside: urban riparian ecology. Frontiers in Ecology and the Environment, 1(6): 315-321.

Grover, D., Singh, J. M. and Kumar, S. (2017). State Agricultural Profile-Punjab. Technical Report, pp. 1-70

Gulati, A. and Juneja, R. (2021). Indian agriculture towards 2030: Pathways for enhancing farmers' income, nutritional security and sustainable food systems, Niti Aayog FAO, 1-27.

Gulati, A., Roy, R. and Saini, S. (2021). Revitalizing Indian Agriculture and Boosting Farmer Incomes pp. 77-112.

Gulati, A., Roy, R., and Hussain, S. (2021). Performance of Agriculture in Punjab. Revitalizing Indian Agriculture and Boosting Farmer Incomes, pp. 77-112.

Hanski, I. (2005). The shrinking world: ecological consequences of habitat loss. International Ecology Institute, Germany,. pp. 307

Hillman, E.J., Bigelow, S.G., Samuelson, G.M., Herzog, P.W., Hurly, T.A., and Rood, S.B. (2016). Increasing river flow expands Riparian habitat: Influences of flow augmentation on channel form, Riparian vegetation and birds along the Little Bow River, Alberta. River Research and Applications, 32: 1687-1697. https://doi.org/10.1002/rra.3018

Ibáñez, C., Curcó, A., Riera, X., Ripoll, I. and, Sánchez, C. (2010). Influence on birds of rice field management practices during the growing season: A review and an experiment. Waterbirds, 33(1): 167-180.

Ivicheva, K.N., Makarenkova, N.N., Zaytseva, V.L., and Philippov, D.A. (2018/ 2019). Influence of flow velocity, river size, a dam, and an urbanized area on biodiversity of lowland rivers. Biosystems Diversity, 26(4): 292-302.

Jackson, B.K., Stock, S.L., Harris, L.S., Szewczak, J.M., Schofield, L.N., and Desrosiers, M.A. (2020). River food chains lead to riparian bats and birds in two mid-order rivers. Ecosphere, 11(6): e03148.

Jahangir, Noor-ud-Din, Tuzak-i-Jahangiri, Ahmad, A. (tr.) (1995). Lahore, Sang-e-Meel Publications, pp. 353.

Jain, S.K., Sarkar, A., and Garg, V. (2008). Impact of declining trend of flow on Harike Wetland, India. Water Resources Manage- 
ment, 22(4): 409-421.

Jansen, A., and Robertson, A.I. (2001). Riparian bird communities in relation to land management practices in floodplain woodlands of south-eastern Australia. Biological Conservation, 100: 173-185.

Jodhka, S.S. (2006). Beyond "Crises": Rethinking contemporary Punjab agriculture, Economic and Political Weekly, 41(16): 1530--1537.

Johnson, R.K. and Hering, D. (2009). Response of taxonomic groups in streams to gradients in resource and habitat characteristics. Journal of Applied Ecology, 46: 175-186.

Kamboj, S., Datta, S.N., Tyagi, A., and Tewari, G. (2021). Assessment of water quality and microbial load in the selected stretches of river Beas in Punjab, India. Journal of Experimental Zoology, 24(1): 435-440.

Kaur, G., and Kler, T.K. (2018). Breeding biology of Black Drongo (Dicrurus macrocercus) in relation to nest-site selection and habitat characterization in agricultural landscape. Journal of Entomology and Zoological Studies, 6(5): 2142-2147.

Kaur, J., Chaudhary, A., Kaur, R., and Arora, S. (2014). Assessment of mutagenic, genotoxic, and cytotoxic potential of water samples of Harike wetland: a Ramsar site in India using different ex vivo biological systems. Ecotoxicology, 23(6): 967977.

Kaur, J., Kler, T.K., Kang, J.S., and Kumar, M. (2016). Avian diversity in relation to cell phone tower in agricultural crop fields of Ludhiana, Punjab, India. International Journal of Advanced Research, 4(1): 492-502.

Kaur, M., and Kumar, M. (2020). Nesting Preferences of Birds in Relation to Exotic Trees in Ludhiana, Punjab. Journal of Animal Research, 10(1): 105-109.

Kaur, M., Singh, S., Singh, J., Singh, J.M., Kingra, H.S. and, Sachdeva, J. (2018). District-wise Cost of Cultivation of Important Crops in Punjab. Department of Economics and Sociology, Punjab Agricultural University, Ludhiana, pp. 1-30.

Kaur, N., and Kumar, M. (2018). Avian diversity in relation to indigenous trees (Doctoral dissertation, Punjab Agricultural University, Ludhiana). Journal of Entomology and Zoology Studies, 6(3): 1739-1745.

Kaur, S., and Kler, T.K. (2018). Breeding bbiology of indian pond heron breeding biology of Indian pond heron ardeola grayii in Punjab, India. The BioScan, 13(2): 729-734.

Kaur, S., and Kler, T.K. (2019). Food and foraging niches of carnivorous bird species in orchards: implications for their conservation. Journal of Animal Research, 9(2): 325-334.

Kelly, J.P., Stralberg, D., Etienne, K. and, McCaustland, M. (2008). Landscape influence on the quality of heron and egret colony sites. Wetlands, 28(2): 257-275.

Kennedy, P.L., DeBano, S.J., Bartuszevige, A.M. and Lueders, A.S. (2009). Effects of native and non-native grassland plant communities on breeding passerine birds: Implications for restoration of northwest bunchgrass prairie. Restoration Ecology, 17(4): 515-525.

Keten, A., Eroglu, E., Kaya, S. and Anderson, J.T. (2020). Bird diversity along a riparian corridor in a moderate urban landscape. Ecological Indicators, 118: 106751.

Khalid, M.A. (2019). Faunal diversity of Ppunjab with special emphasis on the shivalik region: an overview. Biodiversity, Conservation and Systematics, 217.

King, S., Elphick, C.S., Guadagnin, D., Taft, O. and, Amano, T. (2010). Effects of landscape features on waterbird use of rice fields. Waterbirds, 33(1): 151-159.

Kissling, W.D., Rahbek, C., and Böhning-Gaese, K. (2007). Food plant diversity as broad-scale determinant of avian frugivore richness. Proceedings of the Royal Society B: Biological Sciences, 274(1611): 799-808.

Kler, T.K. (2009). Avifaunal diversity in green belts along the Sirhind canal and its branches in Punjab. Environment and Ecology, 27(4A): 1730-1733.

Kler, T.K. and Manoj, K. (2015). Avian fauna in agricultural habitats of Punjab State. Agricultural Research Journal, 52(3): 83-90.

Kler, T.K. and Parshad, R.K. (2012). Avian foraging ecology in relation to phenological stages in mustard crop. Journal of Research, 49(4): 263-268.

Kler, T.K., and Kumar, M. (2015). Prevalence of bird species in relation to food habits and habitat. Agricultural Research Journal, 52(1): 50-53.

Kler, T.K., Kumar, M., and Vashishat, N. (2018). Effects of electromagnetic radiations on diversity and breeding biology of 
birds living near power lines and mobile towers at Ludhiana, Punjab. Journal of Environmental Biology, 39(2): 247-252.

Kler, T.K., Vashishat, N. and Kumar, M. (2015). Bird composition in urban landscape of Punjab. International Journal of Advance Research, 3: 1113-1118.

Kremen, C., and Merenlender, A.M. (2018). Landscapes that work for biodiversity and people. Science, 362(6412): 1-10.

Kumar, M., and Singh, R.K. (2018). Effect of Mobile Tower Radiation on Birds, Rural and Urban Area of Durg District (CG). World Journal of Pharmacy and Pharmaceutical Sciences, 7(6): 1330-1338.

Kumar, R., Vaid, U. and Mittal, S. (2018). Water Crisis: Issues and Challenges in Punjab. In: Singh V., Yadav S., Yadava R. (eds) Water Resources Management. Water Science and Technology Library, Springer, Singapore. 78.

Kumar, V., Sharma, A., Bhardwaj, R., and Thukral, A.K. (2020). Water Quality of River Beas, India, and Its Correlation with Reflectance Data. Journal of Water Chemistry and Technology, 42(2): 134-141.

Kumar, V., Sharma, A., Minakshi, Bhardwaj, R. and Thukral, A.K. (2018). Temporal distribution, source apportionment, and pollution assessment of metals in the sediments of Beas river, India. Human and Ecological Risk Assessment, 24(8): $2162-81$.

Kumar, V., Sharma, A., Thukral, A.K. and Bhardwaj, R. (2017). Water quality of River Beas, India. Current Science, $112(6)$ : 1137 -57 .

Kumar, V., Singh, P. and Singh, V. (2007). Snow and glacier melt contribution in the Beas River at Pandoh dam, Himachal Pradesh, India. Hydrological Ssciences Jjournal, 52(2): 376-388.

Ladhar, S.S. (2002). Status of ecological health of wetlands in Punjab, India. Aquatic Ecosystem Health \& Management, 5(4): 457-465.

Larrieu, L. and Cabanettes, A. (2012). Species, live status, and diameter are important tree features for diversity and abundance of tree microhabitats in subnatural montane beech-fir forests. Canadian Journal of Forest Research, 42(8): 1433-45.

Larsen, S., Soarce, A. and, Mancini, L. (2010). Riparian bird communities as indicators of human impacts along Mediterranean streams. Environmental Management, 45(2): 261--273.

Li, L., Wang, Z., Zerbe, S., Abdusalih, N., Tang, Z., Ma, M. and Fang, J. (2013). Species richness patterns and water-energy dynamics in the drylands of northwest China. PLoS ONE, 8: e66450. https://doi.org/10.1371/journal.pone.0066450

Liang, C., Feng, G., Si, X., Mao, L., Yang, G., Svenning, J.C. and Yang, J. (2018). Bird species richness is associated with phylogenetic relatedness, plant species richness, and altitudinal range in Inner Mongolia Ecology and. Evolution, 8: 53-58. https://doi.org/10.1002/ece3.3606

Liu, W.X., Li, X.D. and Shen, Z.G. (2003). Multivariate statistical study of heavy metal enrichment in sediments of the Pearl River Estuary. Environmental Pollution, 121(3): 377-88.

Lorenzón, R.E., Beltzer, A.H., Olguin, P.F. and Ronchi-Virgolini, A.L. (2016). Habitat heterogeneity drives bird species richness, nestedness and habitat selection by individual species in fluvial wetlands of the Paraná River, Argentina. Austral Ecology, 41(7): 829-841.

Lu, A.H., Perng, J.J., Kuo, W.C., Ueh, C.L., Ting, C.S. and Chen, J.H. (2007). A biodiversity study on the rural ditch landscape in the Wuggo Village, Pingtung County. Taiwan Journal of. Architecture, 59: 163-188.

Luke, S.H., Slade, E.M., Gray, C.L., Annammala, K.V., Drewer, J., Williamson, J. and Struebig, M.J. (2019). Riparian buffers in tropical agriculture: Scientific support, effectiveness and directions for policy. Journal of Applied Ecology, 56: 85-92. https://doi.org/10.1111/1365-2664.13280

Lussier, S.M., Enser, R.W., Dasilva, S.N. and Charpentier, M. (2006). Effects of habitat disturbance from residential development on breeding bird communities in riparian corridors. Environmental Management, 38: 504--521.

Ma, Z., Cai, Y., Li, B. and Chen, J. (2010). Managing wetland habitats for waterbirds: An international perspective. Wetlands, 30: $15-27$.

Mabwoga, S.O. and Thukral, A.K. (2014). Characterization of change in the Harike wetland, a Ramsar site in India, using landsat satellite data. SpringerPlus, 3(1): 1-11.

Mac Nally, R., Ellis, M. and Barrett, G. (2004). Avian biodiversity monitoring in Australian rangelands. Austral Ecology, 29(1): 93-99.

MacGregor-Fors, I. and Schondube, J. E. (2011). Use of tropical dry forests and agricultural areas by Neotropical bird communities. Biotropica, 43: 365-370. 
Macro-Mendez, C., Prado, P., Ferrero-Vicente, L.M., Ibanez, C. and Sanchez-Lizaso, J.L. (2015). Seasonal effects of waterfowl grazing on submerged macrophytes: The role of flowers. Aquatic Botany, 120: 275-282. https://doi.org/10.1016/ j.aquabot.2014.09.006

Mahesh, M., Krishnan, S.M. and Kannan, D.P. (2018). Interactive phenomenon of plants and avian diversity in Vettangudi Bird Sanctuary, Southern India. Science International, 6: 65-70.

Major, R.E., Christie, F.J. and Gowing, G. (2001). Influence of remnant and landscape attributes on Australian woodland bird communities. Biological Conservation,102: 47-66.

Malik, M. and Rai, S.C. (2019). Drivers of land use/cover change and its impact on Pong Dam wetland. Environmental Monitoring and Assessment, 191(4): 1-14.

Maltby, E. and Ormerod, S.J. (2011). Freshwaters: open waters, wetlands and floodplains. In: UK National Ecosystem Assessment, editor. UK national ecosystem assessment: technical report. Cambridge: UNEPWCMC. pp. 295--360.

Manel, S., Buckton, S.T. and Ormerod, S.J. (2000). Testing large- scale hypotheses using surveys: the effects of land use on the habitats, invertebrates and birds of Himalayan rivers. Journal of Applied Ecology, 37(5): 756-770.

Martin, T.G. and Possingham, H.P. (2005). Predicting the impact of livestock grazing on birds using foraging height data. Journal of Applied Ecology, 42: 400-408. https://doi.org/10.1111/j.1365-2664.2005.01012.x

Martin, T.G., McIntyre, S., Catterall, C.P. and, Possingham, H.P. (2006). Is landscape context important for riparian conservation? Birds in grassy woodland. Biological Conservation, 127: 201--214.

Marzluff, J.M. (2001). Worldwide urbanization and its effects on birds. In: Marzluff J.M., Bowman R., Donnelly R. (eds) Avian Ecology and Conservation in an Urbanizing World. Springer, Boston, MA. pp. 19-47 https://doi.org/10.1007/978-1-4615 $-1531-9 \_2$

Mason, C. F. and Macdonald, S.M. (2000). Numbers of wintering waterbirds on rivers in eastern England. Wildfowl, 51(51): 215 -219 .

Mattsson, B.J. and, Cooper, R.J. (2006). Louisiana waterthrushes (Seiurus motacilla) and habitat assessments as cost-effective indicators of instream biotic integrity. Freshwater Biology, 51: 1941-1958.

Mishra, H., Kumar, V. and Kumar, A. (2019). Population structure and habitat utilization of migratory birds at Bakhira Bird Scantuary Uttar Pradesh, India. Pakistan Journal of Zoology, 52: 247-254.

Morris, K. (2000). Avian abundance and diversity in CRP, crop fields, pastures, and restored and native grasslands during winter. Passenger Pigeon, 62: 217-24.

Moza, U. and Mishra, D.N. (2007). River Beas Ecology and Fishery. Central Inland Fisheries Research Institute, Indian Council of Agricultural Research, Barrackpore, West Bengal. Bulletin No. 150.

Murphy, M.T. (2003). Avian population trends within the evolving agricultural landscape of eastern and central United States. Auk, 120: 20-34.

Nakano, S. and Murakami, M. (2001). Reciprocal subsidies: Dynamic interdependence between terrestrial and aquatic food webs. Proceedings of the National Academy of Sciences of the United States of America, 98: 166- 170. https://doi.org/10.1073/ pnas.98.1.166

Nelson, K.S., Gray, E.M. and Evans, J.R. (2011). Finding solutions for bird restoration and livestock management: Comparing grazing exclusion levels. Ecological Applications, 21: 547-554. https://doi.org/10.1890/10-0032.1

Newton, I. (2004). The recent declines of farmland bird populations in Britain: an appraisal of causal factors and conservation actions. Auk, 146: 579-600.

Nimmo, D.G., Haslem, A., Radford, J.Q., Hall, M. and Bennett, A.F. (2016). Riparian tree cover enhances the resistance and stability of woodland bird communities during an extreme climatic event. Journal of Applied Ecology, 53: 449-458. https://doi.org/10.1111/1365-2664.12535

O'Connor, R.J., Walls, T.E. and Hughes (2000). Using multiple taxonomic groups to index the ecological condition of lakes. Environmental Monitoring and Assessment, 61: 207-228.

O'Neal Campbell, M. (2008). The impact of vegetation, river, and urban features on waterbird ecology in Glasgow, Scotland. Journal of Coastal Research, (24): 239- 245.

Ormerod, S.J., Tyler, S.J. and Juttner, I. (2000). Effects of point source PCB contamination on breeding performance and post- 
fledging survival in the dipper Cinclus cinclus. Environmental Pollution. 109(3): 505-513.

Ortega-Álvarez, R., and MacGregor-Fors, I. (2009). Living in the big city: Effects of urban land-use on bird community structure, diversity, and composition. Landscape and urban planning, 90(3-4): 189-195.

Palmer, G.C. and Bennett, A.F. (2006). Riparian zones provide for distinct bird assemblages in forest mosaics of south-east Australia. Biological Conservation, 130: 447- 457. https://doi.org/10.1016/j.biocon.2006.01.005

Palmer, G.C., Fitzsimons, J.A., Antos, M.J. and White, J.G. (2008). Determinants of native avian richness in suburban remnant vegetation: Implications for conservation planning. Biological Conservation, 141: 2329-2341. https://doi.org/10.1016/ j.biocon.2008.06.025

Pannu, K.S. (2018). Illusion of surplus Ravi-Beas waters. Agricultural Research Journal, 55(1): 185-186.

Paul, M.J. and Meyer, J.L. (2001). Streams in the urban landscape. Annual Review of Ecology and Systematics, 32: 333-365.

Pawson, S.M., Brin, A., Brockerhoff, E.G., Lamb, D., Payn, T.W., Paquette, A., Parrotta, J.A. (2013). Plantation forests, climate change and biodiversity. Biodiversity and Conservation, 22: 1203.

Pennington, D.N., Hansel, J. and Blair, R.B. (2008). The conservation value of urban riparian areas for landbirds during spring migration: land cover, scale, and vegetation effects. Biological Conservation, 141(5): 1235-1248.

Piha, M., Tiainen, J., Holopainen, J., and Vepsäläinen, V. (2007). Effects of land-use and landscape characteristics on avian diversity and abundance in a boreal agricultural landscape with organic and conventional farms. Biological Conservation, 140(1-2): 50-61.

Preston, C.D., Telfer, M.G., Arnold, H.R., Carey, P.D., Cooper, J.M., Dines, T.D. Hill, M.O., Pearman, D.A., Roy, D.B., Smart, S.M. (2002). The Changing Flora of the UK, DEFRA, London.

Proenca, V.M. Pereira, H.M., Guilherme, J. and Vicente, L. (2010). Plant and bird diversity in natural forests and in native and exotic plantations in NW Portugal. Acta Oecologica, 36: 219-226.

PSOP (2011) Population Statistics of Punjab. 1971-2011. pPp. 6-57. Government of Punjab, Chandigarh.

Rafie, J. and Kumar, R. (2020). A Review on Scenario of Agriculture in India and Punjab 1900-2019. International Journal of Current Microbiology and Applied Sciences, 9(6): 4149-4170.

Razafimanjato, G., Sam, T.S. and Thorstrom, R. (2007). Waterbird monitoring in the Antsalova region, western Madagascar. Waterbirds, 30(3): 441-447.

Ren, C., Wang, Z., Zhang, B., Li, L., Chen, L., Song, K., and Jia, M. (2018). Remote monitoring of expansion of aquaculture ponds along coastal region of the Yellow River Delta from 1983 to 2015. Chinese geographical science, 28(3): 430-442.

RIS (2020) RIS for Site no. 2408, Beas Conservation Reserve, India, Ramsar Information Sheet, pp. 1-15

Rizvi, R.H., Handa, A.K., Sridhar, K.B., Singh, R.K., Dhyani, S.K., Rizvi, J. and Dongre, G. (2020). Spatial analysis of area and carbon stocks under Populus deltoides based agroforestry systems in Punjab and Haryana states of Indo-Gangetic Plains. Agroforestry Systems, 94(6): 2185-2197.

Sabo, J.L., Sponseller, R., Dixon, M., Gade, K., Harms, T., Heffernan, J., Jani, A., Katz, G., Soykan, C., Watts, J. and Welter, J. (2005). Riparian zones increase regional species richness by harboring different, not more, species. Ecology, 86(1): 56-62.

Saklani, A., Naithani S., and Saini, K.S. (2018)."Effect of urbanization in birds diversity: a case of Doon valley. Journal of Biodiversity and Management and Forestry, 7(3): 6. doi: 10.4172/2327-4417.1000204.

Saresh, N.V., Verma, A., Bhople, B.S., Kumar, A. and Kanive, M. (2018). Habitat trees: Key elements for avian biodiversity. Trends in Ecology \& Environment, 1(1): 1-4.

Sarkar, A., and Jain, S.K. (2008). Using Remote Sensing data to study wetland dynamics-A case study of Harike Wetland. In Proceedings of Taal 2007: The 12th World Lake Conference, 680: 684.

Sekercioglu, C.H., Daily, G.C. and Ehrlich, P.R. (2004). Ecosystem consequences of bird declines. Proceedings of National Academy of Sciences, 101:18042-47.

Sethi, J. and Kumar, M. (2018). Abundance and habitat ecology of Asian pied starling (Sturnus contra) in agricultural ecosystem of Punjab, India. Journal of Entomology and Zoology Studies, 6(2): 1193-1196.

Seto, K.C., Parnell, S. and Elmqvist, T. (2013). A global outlook on urbanization Urbanization, biodiversity and ecosystem services: Challenges and opportunities, Netherlands: Springer. pp. 1-12.

Sharma, S., and Walia, Y.K. (2017). Analysis of metal content in water of River Beas in Himachal Pradesh, India. Oriental 
Journal of Chemistry, 33(1): 514.

Sharma, S., Reddy, A.S. and Dalwani, R. (2017). Water Quality Management Studies on the River Satluj for the Protection of the Harike Wetland System (Doctoral dissertation).

Shirley, S.M., and Smith, J.N.M. (2005). Bird community structure across riparian buffer strips of varying width in a coastal temperate forest. Biological Conservation, 125: 475- 489. https://doi.org/10.1016/j.biocon.2005.04.011

Siddiqui , A., Ahmed, T., and Afifullah, Khan.K.H.A.N. (2019). Avifaunal Assemblage along Rural-Urban Gradients in Aligarh, Uttar Pradesh, India. Notulae Scientia Biologicae, 11(4): 421-427.

Sidhu, H.S. (2005). Production condition in contemporary Punjab Agriculture, Journal of Punjab Studies, 12(2): 197- 219.

Sidhu, S.K. and Kler, T.K. (2017). Fruit tree diversity as broad-scale determinant of avian species richness in Punjab. Agricultural Research Journal, 54(1): 65-71.

Sidhu, S.K. and Kler, T.K. (2018). Avian composition and damage assessment in guava fruit crop at Ludhiana, Punjab. Journal of Entomology and Zoology Studies, 6: 2422-2426.

Sidhu, S.K. and Kler, T.K. (2021). Assessment of Heavy Metal Contamination in Excreta of Baya Weaver Bird (Ploceus Philippinus) from Three Districts of Different Zones of Punjab. Bulletin of Environmental Contamination and Toxicology, 106(5): 799804.

Sidhu, S.K., Sekhon, G.S., Aulakh, R.K. and Kler, T.K. (2021). Prioritizing Sustenance of Village Ponds for Avian Conservation: A Case Study from Punjab, India. Pakistan Journal of Zoology, 53(2): 1-8.

Singh, S., Bhardwaj, A., and Verma, V.K. (2020). Remote sensing and GIS based analysis of temporal land use/land cover and water quality changes in Harike wetland ecosystem, Punjab, India. Journal of environmental management, $262: 110355$.

Sinha, A., Chatterjee, N., Ormerod, S.J., Adhikari, B.S., and Krishnamurthy, R. (2019). River birds as potential indicators of local-and catchment-scale influences on Himalayan river ecosystems. Ecosystems and People, 15(1): 90-101.

Sirhindi, Ahmad, Y.B., Tarikh-i-Mubarak, S., Beveridge, H. (tr.) (1990). Delhi, Low Price Publications. 175: 191 - 215.

Smith, S.V., Renwick, W.H., Bartley, J.D. and Buddemeier, R.W. (2002). Distribution and significance of small, artificial water bodies across the United States landscape. Science of Total Environment, 299: 21-36. https://doi.org/10.1016/S0048-9697 (02)00222-X

Soni, S., Kler, T.K. and Javed, M. (2019). Emerging threat of urbanization to ponds and avian fauna in Punjab, India. Journal of Entomology and Zoological Studies, 7: 1310-1315.

Sotherton, N.W. and, Self, M.J. (2000). Changes in plant and arthropod biodiversity on lowland farmland: an overview. In: Aebischer, N.J., Evans, A.D., Grice, P.V., Vickery, J.A. (Eds.), Ecology and Conservation of Lowland Farmland Birds. British Ornithologists Union, Tring, UK, pp. 26--35.

Srivastava, S.K., Ramesh, C., Raju, S.S., Jain, R., Kingsly, I., Sachdeva, J., Singh, J. and Kaur, A.P. (2015) Unsustainable Groundwater Use in Punjab Agriculture: Insights from Cost of Cultivation Survey. Indian Journal of Agricultural Economics. Jn. of Agri. Econ. 70(3): 365-378.

Srivastava, V.K. (2007). River ecology in India: present status and future research strategy for management and conservation. Proceedings of -Indian National Science Academy, 73(4): 255.

Stoate, C., Boatman, N.D., Borralho, R.J., Carvalho, C.R., de Snoo, G.R. and Eden, P. (2001). Ecological impacts of arable intensification in Europe. Journal of Environmental Management 63: 337-365.

Sullivan, S.M.P., Watzin, M.C. and Keeton, W.S. (2007). A riverscape perspective on habitat associations among riverine bird assemblages in the Lake Champlain Basin, USA. Landscape Ecology, 22: 1169-1186. https://doi.org/10.1007/s10980-0079097-3

Surendran, N.S., Siddiqui, N.A., Mondal, P. and Nandan, A. (2020). Repercussion of Electromagnetic Radiation from Cell Towers/Mobiles and Their Impact on Migratory Birds. In: Siddiqui, N., Tauseef, S., Abbasi, S., Khan, F. (eds) Advances in Air Pollution Profiling and Control. Springer Transactions in Civil and Environmental Engineering. Springer, Singapore. https://doi.org/10.1007/978-981-15-0954-4_12

Takahashi, M. and, Ohkawara, K. (2007) Breeding behavior and reproductive success of Grey-headed Lapwing Vanellus cinereus on farmland in central Japan. Ornithological Science, 6(1): 1-9.

Terraube, J., Archaux, F., Deconchat, M., Van Halder, I., Jactel, H. and Barbaro, L. (2016). Forest edges have high conservation 
value for bird communities in mosaic landscapes. Ecology and Evolution, 6(15): 5178-5189. https://doi.org/10.1002/ ece 3.2273

Tilman, D., Fargione, J., Wolff, B., D’Antonio, C., Dobson, A., Howarth, R., Schindler, D., Schlesinger, W.H., Simberloff, D. and Swackhamer, D. (2001). Forecasting agriculturally driven global environmental change. Science, 292: 281-284.

Uluturhan, E. and Kucuksezgin, F. (2007). Heavy metal contaminants in Red Pandora (Pagellus erythrinus) tissues from the Eastern Aegean Sea, Turkey. Water Research 41(6): 1185-92.

Urban, M.C., Skelly, D.K., Burchsted, D., Price, W. and Lowry, S. (2006). Stream communities across a rural-urban landscape gradient. Diversity and Distributions, 12: 337-350.

Vandewalle, M., de Bello, F., Berg, M.P., Bolger, T., Doledec, S. and Dubs, F.(2010). Functional traits as indicators of biodiversity response to land use changes across ecosystems an organisms. Biodiversity Conservation, 19: 2921-2947.

Vaughan, I.P., Noble, D.G. and, Ormerod, S.J. (2007). Combining surveys of river habitats and river birds to appraise riverine hydromorphology. Freshwater Biology, 52: 2270-2284.

Vickery, J.A., Ewing, S.R., Smith, K.W., Pain, D.J., Bairlein, F., Škorpilová, J., and Gregory, R.D. (2014). The decline of AfroPalaearctic migrants and an assessment of potential causes. Ibis, 156: 1-22. https://doi.org/10.1111/ibi.12118.

Walsh, C. J., Roy, A.H., Feminella, J.W., Cottingham, P.D., Groffman, P.M. and Morgan, R.P. (2005). The urban stream syndrome Current knowledge and the search for a cure. Journal of the North American Benthological Society, 24: 706-723.

Waltert, M., Mardiastuti, A. and, Muhlenberg, M. (2004) Effects of land use on bird species richness in Sulawesi, Indonesia. Conservation Biology, 18(5): 1339-1346.

Wenny, D.G., De Vault, T.L., Johnson, M.D., Kelly, D., and Sekercioglu, C.H. (2011). The need to quantify ecosystem services provided by birds. The Auk, 128(1): 1-14.

Williams, R.T., and Fryirs, K.A. (2020). The morphology and geomorphic evolution of a large chain-of-ponds river system. Earth Surface Processes and Landforms, 45(8): 1732-1748.

Woinarski, J.C., Brock, C., Armstrong, M., Hempel, C., Cheal, D. and Brennan, K. (2000). Bird distribution in riparian vegetation in the extensive natural landscape of Australia's tropical savanna: a broad scale survey and analysis of a distributional data base. Journal of Biogeography, 27: 843-868.

Wood, C., Qiao, Y., Li, P., Ding, P., Lu, B., Xi, Y. (2010) Implications of rice agriculture for wild birds in China. Waterbirds, 33 (1): 30-43.

Wu, H., Lai, C., Zeng, G., Liang, J., Chen, J., Xu, J., Dai, J., Li, X., Liu, J., Chen, M., Lu, L., Hu, L. and, Wan, J. (2017). The interactions of composting and biochar and their implications for soil amendment and pollution remediation: a review. Critical Reviews in Biotechnology, 37(6): 754e764.

Yadgaar, A., Tarikh-i-Shahi and Nazir Niazi (tr.) (1985). Lahore: Urdu Science Board. pp. 36.

Yi, Y., Yang, Z. and Zhang, S. (2011). Ecological risk assessment of heavy metals in sediment and human health risk assessment of heavy metals in fishes in the middle and lower reaches of the Yangtze River basin. Environmental Pollution, 159 (10): 2575-85.

Zou, F., Yang, Q., Dahmer, T., Cai, J. and, Zhang, W. (2006) Habitat use of waterbirds in coastal wetland on Leizhou Peninsula, China. Waterbirds, 29(4): 459-464.

*****

Cite this chapter as: Kumar, S. and Kler, T.K. (2021). Avian diversity at Beas River conservation reserve under urbanization and intensive agriculture in Punjab, India. In: Biological Diversity: Current Status and Conservation Policies, Volume 1, Eds. Kumar., V., Kumar, S., Kamboj, N., Payum, T., Kumar, P. and Kumari, S. pp. 167-192, https:// doi.org/10.26832/aesa2021-bdcp-011 